\title{
Occipital Condyle Fractures in Traumatic Brain Injury-A Review
}

\section{Fraturas de côndilo occipital no trauma cranioencefálico - uma revisão}

\author{
Guilherme Brasileiro de Aguiar ${ }^{1}$ Aline Lariessy Campos Paiva ${ }^{2}$ Marcos Antonio Duarte Madeiro Filho ${ }^{2}$ \\ Vinícius Monteiro de Paula Guirado ${ }^{1}$ José Carlos Esteves Veiga ${ }^{3}$
}

\footnotetext{
${ }^{1}$ Department of Surgery, Division of Neurosurgery, Faculdade de Ciências Médicas da Santa Casa de Misericórdia de São Paulo, São Paulo, Brazil

${ }^{2}$ Department of Surgery, Division of Neurosurgery, Faculdade de Ciências Médicas da Santa Casa de Misericórdia de São Paulo, São Paulo, Brazil

${ }^{3}$ Division of Neurosurgery, Faculdade de Ciências Médicas da Santa Casa de Misericórdia de São Paulo, São Paulo, Brazil
}

Address for correspondence Guilherme Brasileiro de Aguiar, MD, MSc, Division of Neurosurgery, Santa Casa de São Paulo Medical School, Rua Cesário Motta Jr., 112-Vila Buarque, 01221-900 São Paulo, SP, Brazil (e-mail: guilhermebraguiar@yahoo.com.br).

Arq Bras Neurocir 2015;34:203-207.

\section{Resumo \\ Palavras-Chave \\ - côndilo \\ - fratura de côndilo occipital \\ - trauma cranioencefálico}

É bem estabelecido que o diagnóstico da fratura de côndilo occipital tem aumentado nas últimas décadas, provavelmente devido à disponibilidade e ao uso comum da tomografia computadorizada durante a investigação do trauma craniano, além da maior gravidade dos mecanismos de trauma. Por causa da baixa especificidade da apresentação clínica, e também pelo pouco conhecimento sobre o mecanismo de lesão, o diagnóstico desta condição é um desafio para neurocirurgiões. A abordagem terapêutica destes pacientes é baseada em estudos com baixa casuística e em relatos de caso. Uma revisão sobre este tema foi realizada a fim de discutir alguns aspectos controversos sobre o manejo da fratura de côndilo occipital. As fraturas de côndilo occipital são eventos raros, entretanto podem relacionar-se à alta morbidade em pacientes que sofreram trauma encefálico. Alguns sintomas, como intensa dor cervical, podem estar associados com esta fratura; portanto, paciente com suspeita de fratura de côndilo occipital deve ser submetido a investigação radiológica detalhada da região. O diagnóstico precoce desta fratura permite investigação apropriada, minimizando a chance de sequelas.

It is well established that diagnoses of occipital condyle fracture have increased in past decades, probably because of the availability and common use of computed tomography for investigating traumatic brain injuries, as well as the major seriousness of trauma mechanism. Because of the low specificity of clinical presentation besides the lesion mechanism not well known, this condition is a diagnostic challenge for neurosurgeons. Therapeutic approaches of these patients are based on studies with low samples and case reports. A review of this theme was performed objecting to discuss some received

April 16, 2014

accepted

June 12, 2015
DOI http://dx.doi.org/

10.1055/s-0035-1560027. ISSN 0103-5355.
Copyright $\odot 2015$ by Thieme Publicações License terms

Ltda, Rio de Janeiro, Brazil 
controversial topics about management of occipital condyle fracture. The occipital condyle fracture is a rare event, and it, however, could be related to high morbidity in patients who suffered traumatic brain injury. Some symptoms such as severe neck pain are related with this fracture, and thus patients suspicious of this fracture should undergo detailed radiologic investigation of this region. Early diagnosis of this fracture allows appropriate investigation, thus minimizing the risk of sequelae.

\section{Introduction}

Traumatic brain injury (TBI) causes several types of lesions, depending on factors such as mechanism, intensity, and localization of the impact. ${ }^{1}$ Cranium constitutes an important and rigid bony framework that protects the encephalic tissue from more serious lesions; therefore cranial bone fracture is generally associated with higher-impact traumas.

Occipital fracture, such as in the condyle, is rare due to its anatomical position. Temporoparietal lesions are more common in this context. ${ }^{1}$ However, occipital condyle fracture (OCF) remains as a severe injury.

Some structures provide stability to this condyle region; they are the tectorial membrane and the alar ligaments, which fix cranium to vertebrae $\mathrm{C} 2$ and $\mathrm{C}^{2}{ }^{2}$ Owing to its proximity to hypoglossal canal and jugular foramen, in addition to its close relation with brainstem, OCF could associate with severe clinical manifestations.

\section{Methods}

A literature review about this theme was performed using articles published in some databases such as PUBMED and LILACS, mainly in the past years. A sample of these manuscripts was selected and this review was made. During the research, the following keywords were used: "condyle," "occipital condyle fracture," and "traumatic brain injury."

\section{Discussion}

OCFs constitute a rarely diagnosed lesion because of low suspicion during initial evaluation, despite that neuroimaging methods, such as computed tomography (CT), are capable of revealing these kind of alterations. It was in 1817 when OCF was first described by Sir Charles Bell ${ }^{2}$ during autopsy analysis. His patient suddenly died of the fracture instability in a region with a complex anatomy and related with noble structures, as well as the medulla. Clinical presentation varies a lot, which promotes low suspicion in patients who have suffered TBI.

Some signs suggest that an OCF could be present. Noble and $\mathrm{Smoker}^{2}$ evaluated 15 patients and described the following clinical presentation: cranial nerve palsy (mainly XII cranial nerve) and trauma to other organs, such as clavicle, mandible, and humeral fracture and epidural hematoma, ${ }^{2}$ revealing the high mechanism of the injury. This study also revealed the importance of understanding the trauma mechanism, insofar as high-level impacts, mainly motor vehicle accidents, are mostly related with an unstable OCF.

Other signs are also described as more associated with OCF, and so when a patient presents with these signs, CT of the craniocervical junction should be performed. These signs include persistent neck pain instead of normal cervical spine radiography, torticollis, cranial nerve palsy (IX, X, XI, and XII), and retropharyngeal or prevertebral posttraumatic edema and fracture or dislocation of the high cervical spine. ${ }^{3}$ In current trauma evaluation, $\mathrm{CT}$ of a cranial and cervical spine may not reveal these fractures, because it depends on thickness and inclination of slices, so a specific incidence could be necessary for a better evaluation.

Waseem et $\mathrm{al}^{4}$ also emphasize that a patient could only present with symptoms of OCF some days after the TBI and, based on clinical presentation and trauma mechanism, could deserve accurate investigation. ${ }^{4}$ They described a patient who presented to emergency department (ED) with severe neck pain but no other significant alterations either in general and neurologic examination several days after a trauma, and an OCF was diagnosed after investigation. ${ }^{4}$

The anatomy of this region is related with the symptoms previously described. The occipital condyle has close proximity to the hypoglossal canal and jugular foramen, which could affect the nerves IX, X, XI, and XII, besides brainstem causing medulla compression and therefore respiratory distress. ${ }^{5}$ OCF occurs due to trauma with high kinetic energy transmission, generally in motor vehicle accidents. The exact trauma mechanism is not known, but many researchers indicate neck hyperextension associated with vertical force above craniocervical junction as a possible cause. $^{6}$

In most cases, OCF is not associated with neurologic impairment, so it is important to identify it during the diagnosis procedures performed in ED because it has potential of bringing late neurologic deficits due to fracture bone fragment migration or callus formation. ${ }^{2,7}$ Cranial nerves $\mathrm{CN}$ can be injured concomitantly in $31 \%$ of OCF cases. ${ }^{3}$

Although is a rare type of fracture (with incidence ranges from 4 to $19 \%$ of all patients with TBI), ${ }^{8}$ OCF diagnosis has significantly increased in the past decades since it was first described, probably because of the common use of CT during investigation of TBI. The high-resolution CT with sagittal and coronal reconstruction is the standard diagnostic method because it allows visualizing skull base and does not require patient drive. Although if there is no craniocervical instability, bone window in coronal plane could complement the 


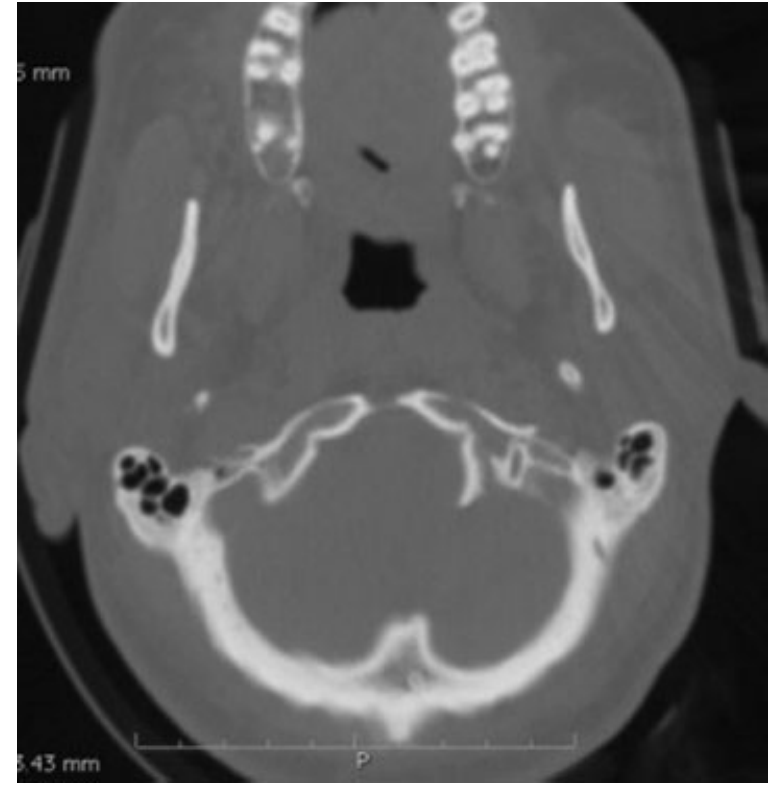

Fig. 1 Cranial computed tomography (axial) showing left occipital condyle fracture, classified as type II of Anderson and Montesano or type 1 of Tuli et al. ${ }^{3}$

examination due to the capacity of ligamentous integrity and

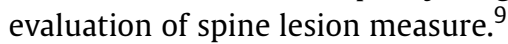

Despite the fact that OCF was first described in $1817,{ }^{10}$ only in 1988 a classification was proposed by Anderson and Montesano (A\&M). ${ }^{11,12}$ They had observed six cases and suggested a classification that correlates trauma mechanism with the fracture morphology.

Three types were described according to fracture condyle conformation. ${ }^{10}$ I-comminuted condyle fracture, without luxation, by cranium compression above the atlas, similar to Jefferson fracture ${ }^{13}$; II-linear fracture, occurring as a part of the posterior skull base fracture, and its mechanism is by direct impact under the cranium; and III-occipital condyle avulsion, usually with medial dislocation of the fracture fragment, which causes instability of the atlantoccipital joint by alar ligament lesion, and its mechanism is described as arising from rotation or lateral twist or by a combination of both movements. The third type could cause pain and movement limitation being associated with lower cranial nerves palsy (-Figs. 1-4).

Tasdemiroğlu and Patchell ${ }^{14}$ added a type IV to the classic A\&M classification. It is characterized by bilateral type I OCF and is considered potentially unstable because both alar ligaments become functionally inadequate. Another classification was proposed by Tuli et $\mathrm{al}^{3}$ in 1997. They considered the ligament lesion grade that was evaluated by the presence of OCF dislocation and by instability of the joints $\mathrm{O}-\mathrm{C} 1-\mathrm{C} 2$ in spine cervical radiography, $\mathrm{CT}$, or magnetic resonance imaging (MRI). Instability criteria are described here:

- More than 8 degrees of axial rotation for one of the $\mathrm{O}-\mathrm{C} 1$ joint side

- More than $1 \mathrm{~mm} \mathrm{O-C1} \mathrm{joint} \mathrm{translation}$

- More than $7 \mathrm{~mm}$ of $\mathrm{C} 1$ sliding above C2

- More than 45 degrees of axial rotation for one side of C1-C2 joint

- More than $4 \mathrm{~mm}$ of $\mathrm{C} 1-\mathrm{C} 2$ joint translation

- More than $13 \mathrm{~mm}$ of distance between C2 body and C1 posterior arch

- Evidence of transverse ligament avulsion in MRI

This new classification also includes the following types of OCF: 1-without dislocation; 2A-with dislocation and $\mathrm{O}-\mathrm{C} 1-\mathrm{C} 2$ joint stability; and $2 \mathrm{~B}-$ with instability of $\mathrm{O}-\mathrm{C} 1-$ C2 joint. $^{3}$

The classification of Tuli et $\mathrm{al}^{3}$ is based on ligament lesion grade, and therefore is more functional and withdraws the emphasis on the occipital condyle anatomy and highlights the $\mathrm{O}-\mathrm{C} 1-\mathrm{C} 2$ joint functional mobility. A\&M types I and II match with type 1 of Tuli et al, ${ }^{3}$ despite A\&M type III match with type 2 of Tuli et al, which is also classified in type A or B according to the presence or absence of O-C1-C2 instability 6 (-Figs. 1-4).

The decision between surgical or conservative approach is difficult and not well established in literature. Before A\&M
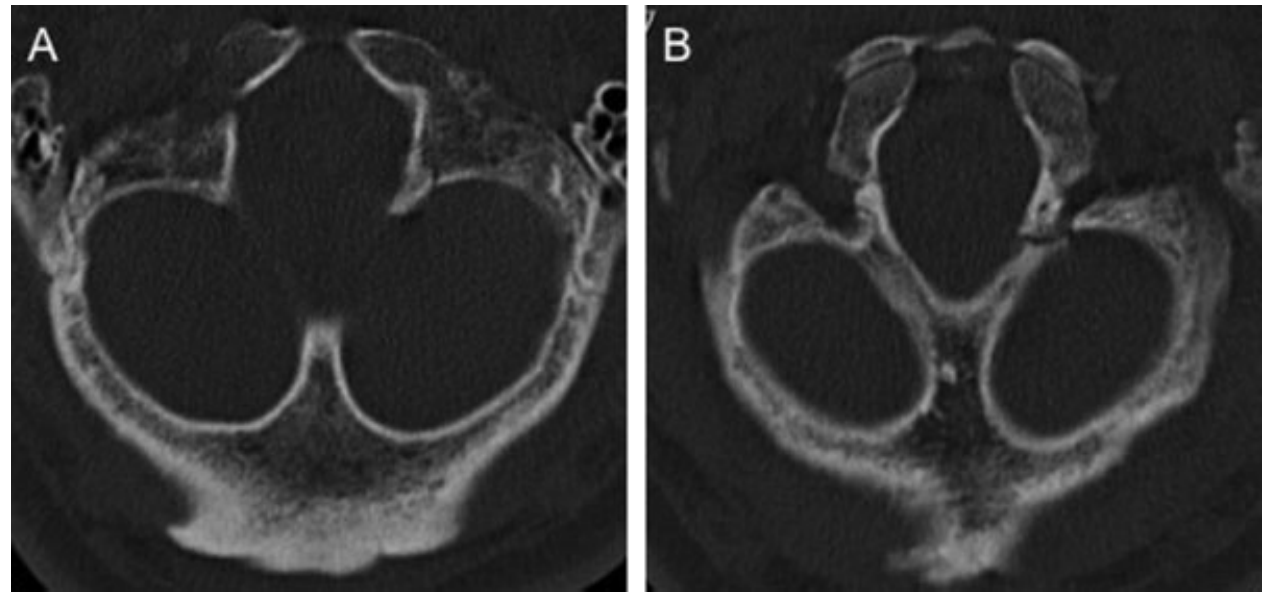

Fig. 2 Cranial computed tomography (A/B-axial) showing left occipital condyle fracture, classified as type II of Anderson and Montesano or type 1 of Tuli et al. ${ }^{3}$ 

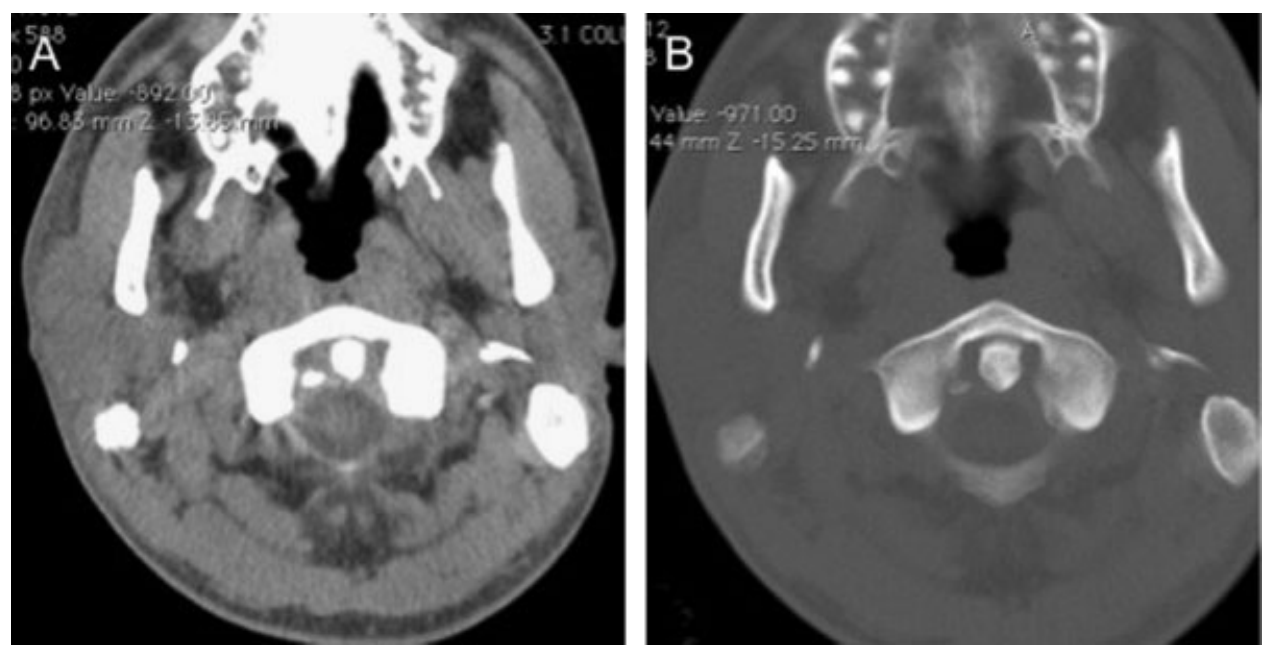

Fig. 3 Cranial computed tomography (A/B-axial) showing right occipital condyle fracture, classified as type III of Anderson and Montesano or type $2 \mathrm{~A}$ of Tuli et al. ${ }^{3}$
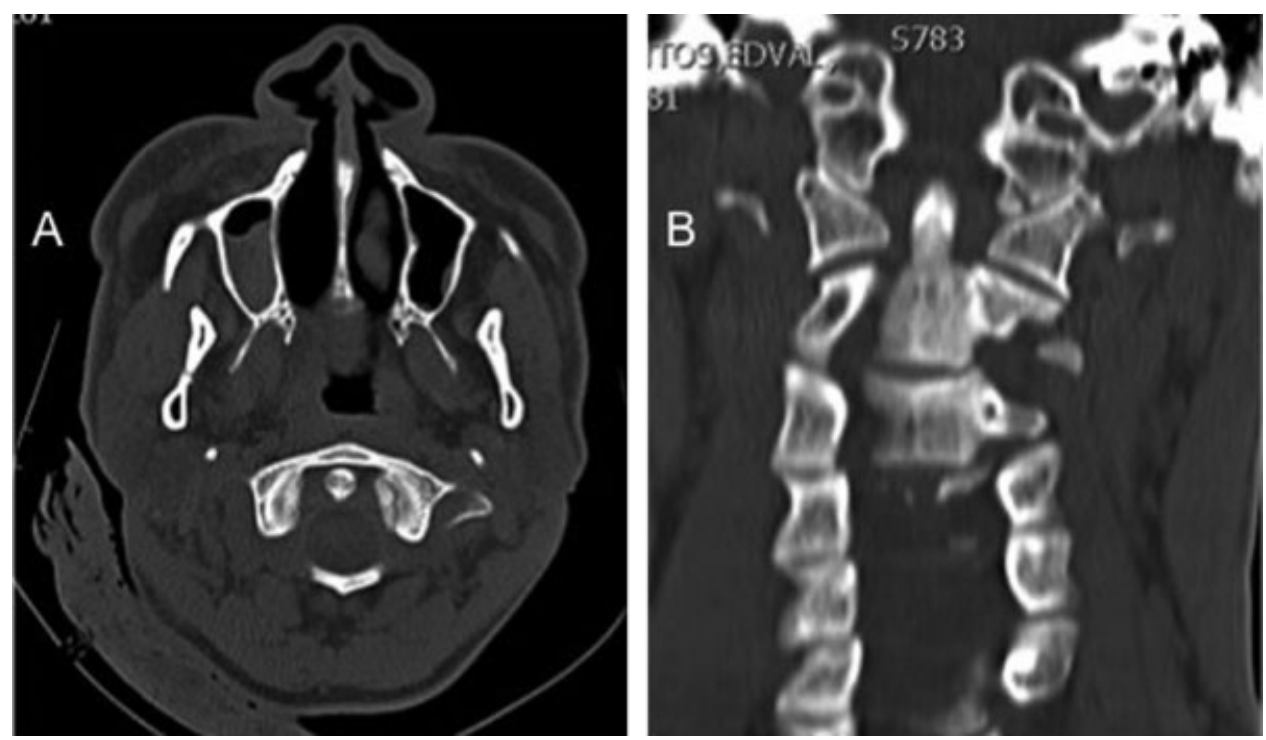

Fig. 4 Computed tomography (A-cranial, axial; B-cervical spine, coronal) showing left occipital condyle fracture, classified as type III of Anderson and Montesano or type $2 \mathrm{~A}$ of Tuli et al. ${ }^{3}$

classification, type III fractures were treated with halo vest immobilization followed by occipitocervical fusion, but in the past years some reports revealed that some type III fractures may be treated with cervical orhosis. ${ }^{15}$ The problem is that the instability criteria for the kind of decision are not well described in these reports.

However, after Tuli et al ${ }^{3}$ classification, it is recommended using their instability criteria previously described to guide the clinical management. Thus, following these authors, OCF type I usually do not require immobilization, OCF type $2 \mathrm{~A}$ must be treated with cervical collar, whereas treatment with external rigid immobilization or surgical fixation is recommended in type 2 B. Bozboga et $\mathrm{al}^{16}$ also recommend, in some cases, surgical treatment in unstable fractures that are associated with acute complications such as neurovascular compression.

In 2009 Maserati el al ${ }^{17}$ also studied surgical management in patients with OCF. During a 6-year period, they identified
100 patients with 106 OCFs. All patients were evaluated by the spine trauma service and they underwent imaging of the craniocervical junction using reconstructed CT scans. ${ }^{17}$ They were treated with a conservative management of A\&M type I. One of them who presented also with an atlantoccipital fracture was surgically approached, and they concluded advocating that OCF precipitating disruption of the occipito- $\mathrm{C1}$ joint should be treated with occipitocervical fusion, and in absence of neural compression and misalignment of cranial cervical junction, OCF could be treated with rigid cervical orthosis for 6 weeks. ${ }^{17}$ But in cases in which the fracture is bilateral, the clinical decision should be more accurate.

\section{Conclusion}

The OCF is a rare event, and, however, could be related to high morbidity in patients who had suffered traumatic brain 
injury. Some symptoms such as severe neck pain are associated to this fracture, and thus patients suspect of OCF should undergo detailed radiologic investigation of this region. Early diagnosis of this fracture allows appropriate investigation, thus minimizing the risk of sequelae. According to the type of the lesion, conservative treatment can also be considered, but clinical observation is required. Prognosis depends on the extent of involvement. Mainly if affects important regions, such as jugular foramen, it may cause neurologic deficits, or even severe disability if the medulla was affected.

\section{References}

1 Bruns J Jr, Hauser WA. The epidemiology of traumatic brain injury: a review. Epilepsia 2003;44(Suppl 10):2-10

2 Noble ER, Smoker WR. The forgotten condyle: the appearance, morphology, and classification of occipital condyle fractures. AJNR Am J Neuroradiol 1996;17(3):507-513

3 Tuli S, Tator CH, Fehlings MG, Mackay M. Occipital condyle fractures. Neurosurgery 1997;41(2):368-376, discussion 376-377

4 Waseem M, Upadhyay R, Al-Husayni H, Agyare S. Occipital condyle fracture in a patient with neck pain. Int J Emerg Med 2014;7(1):5

5 Schrödel MH, Kestlmeier R, Trappe AE. Bilateral occipital condyle fracture: report of two cases. Skull Base 2002;12(2):93-96

6 Gusmão SS, Silveira RL, Arantes A. Tratamento cirúrgico da fratura do côndilo occipital: relato de caso. Arq Neuropsiquiatr 2001; 59(1):134-137
7 Orbay T, Aykol S, Seçkin Z, Ergün R. Late hypoglossal nerve palsy following fracture of the occipital condyle. Surg Neurol 1989; 31(5):402-404

8 Karam YR, Traynelis VC. Occipital condyles fractures. Neurosurgery 2010;66:A56-A59

9 Urculo E, Arrazola M, Arrazola M Jr, Riu I, Moyua A. Delayed glossopharyngeal and vagus nerve paralysis following occipital condyle fracture. Case report. J Neurosurg 1996;84(3): 522-525

10 Bell C. Surgical observations. J Middlesex Hosp 1817;4:469-470

11 Anderson PA, Montesano PX. Morphology and treatment of occipital condyle fractures. Spine 1988;13(7):731-736

12 Taşdemiroğlu E, Kaya M, Yıldırım CH, Fırat L. Occipital condyle fractures. J Neurosurg Spine 2011;14(6):803-804, author reply 803-804

13 Dettling SD, Morscher MA, Masin JS, Adamczyk MJ. Cranial nerve IX and X impairment after a sports-related Jefferson (C1) fracture in a 16-year-old male: a case report. J Pediatr Orthop 2013;33(3): e23-e27

14 Taşdemiroğlu E, Patchell RA. Classification and management of skull base fractures. Neurosurg Quat 2002;12:42-62

15 Maddox JJ, Rodriguez-Feo JA III, Maddox GE, Gullung G, McGwin G, Theiss SM. Nonoperative treatment of occipital condyle fractures: an outcomes review of 32 fractures. Spine 2012;37(16): E964-E968

16 Bozboga M, Unal F, Hepgul K, Izgi N, Turantan MI, Turker K. Fracture of the occipital condyle. Case report. Spine 1992; 17(9):1119-1121

17 Maserati MB, Stephens B, Zohny Z, et al. Occipital condyle fractures: clinical decision rule and surgical management. J Neurosurg Spine 2009;11(4):388-395 